\title{
Drosophilidae (Diptera) associated to fungi: differential use of resources in anthropic and Atlantic Rain Forest areas
}

\author{
Marco S. Gottschalk ${ }^{1}$, Luís Bizzo ${ }^{2}$, Jonas S. Döge ${ }^{1}$, Marcos S. Profes ${ }^{3}$, \\ Paulo R. P. Hofmann ${ }^{3} \&$ Vera L. S. Valente ${ }^{1}$
}

\begin{abstract}
1. Laboratório de Drosophila, Departamento de Genética, Instituto de Biociências, Universidade Federal do Rio Grande do Sul, Avenida Bento Gonçalves, 9500, Caixa Postal 15053, 91501-970 Porto Alegre, RS, Brazil. (gotts007@yahoo.com; jdoge@hotmail.com; vera.gaiesky@ufrgs.br)

2. Universidade de São Paulo, Faculdade de Filosofia, Ciências e Letras de Ribeirão Preto, Programa de Pós-Graduação em Entomologia, Avenida Bandeirantes, 3900, Bloco 2, 14049-900 Ribeirão Preto, SP, Brazil. (luisbizzo@usp.br)

3. Laboratório de Drosofilídeos, Departamento de Biologia Celular, Embriologia e Genética, Centro de Ciências Biológicas, Universidade Federal de Santa Catarina, 88036-400 Florianópolis, SC, Brazil. (marcos_s_p@yahoo.com.br; prph@ccb.ufsc.br)
\end{abstract}

\begin{abstract}
This study investigates the Drosophilidae species associated to fruiting bodies of fungi in forested and anthropized environments of the Atlantic Rain Forest Biome, in south and southeastern Brazil. We collected samples of imagoes flying over and emerging from fruiting bodies of species of five fungi families, in six collection sites. We obtained 18 samples, from which emerged 910 drosophilids of 31 species from the genera Drosophila Fallen, 1823, Hirtodrosophila Duda, 1923, Leucophenga Mik, 1886, Mycodrosophila Oldenberg, 1914, Scaptomyza Hardy, 1849, Zaprionus Coquillett, 1901 and Zygothrica Wiedemann, 1830. The Drosophila species collected on fungi, as well as Zaprionus indianus Gupta, 1970, had previously been recorded colonizing fruits, demonstrating their versatility in resource use. Most of these species belong to the immigrans-tripunctata radiation of Drosophila. Our records expands the mycophagous habit (feeding or breeding on fungi) to almost all species groups of this radiation in the Neotropical region, even those supposed to be exclusively frugivorous. Assemblages associated to fungi of forested areas were more heterogeneous in terms of species composition, while those associated to fungi of anthropized areas were more homogeneous. The drosophilids from anthropized areas were also more versatile in resource use.
\end{abstract}

KEYWORDS. Drosophila, mycophagous insects, feeding sites, breeding sites.

RESUMO. Drosophilidae (Diptera) associados a fungos: uso diferenciado de recursos em áreas antrópicas e de Mata Atlântica. Foi realizado um estudo das espécies de Drosophilidae associadas aos corpos de frutificação de fungos em ambientes florestais e antrópicos no Bioma Mata Atlântica, no sul e sudeste do Brasil. Foram realizadas coletas de adultos sobrevoando e emergindo de corpos de frutificação de espécies de fungos de cinco famílias, em seis pontos de coleta. Foram obtidas 18 amostras, onde foram coletados 910 indivíduos de 31 espécies, pertencentes aos gêneros Drosophila Fallen, 1823, Hirtodrosophila Duda, 1923, Leucophenga Mik, 1886, Mycodrosophila Oldenberg, 1914, Scaptomyza Hardy, 1849, Zaprionus Coquillett, 1901 e Zygothrica Wiedemann, 1830. As espécies de Drosophila coletadas, assim como Zaprionus indianus Gupta, 1970, já haviam sido registradas em frutos, evidenciando sua versatilidade na utilização dos recursos. A maioria destas espécies pertence à radiação immigrans-tripunctata de Drosophila. Em espécies desta radiação que habitam regiões temperadas, a micofagia é amplamente difundida; nossos registros (de sítios de alimentação e oviposição em fungos) expandem este hábito para quase todos os grupos de espécies desta radiação na região Neotropical, mesmo aquelas que se supunham ser exclusivamente frugívoras. As assembléias colonizadoras dos corpos de frutificação variaram entre as espécies de fungos e com o tipo de ambiente em que eles se desenvolviam, onde as espécies de drosofilídeos generalistas utilizam os fungos em ambientes mais degradados.

PALAVRAS-CHAVES. Drosophila, insetos micófagos, sítios de alimentação, sítios de oviposição.

Mycophagy has manifested itself several times in the evolution of Drosophilidae, and it is very likely that it derived from detrivorous habits (THROскMORTON, 1975). Some genera, like Drosophila Fallen, 1823, Leucophenga Mik, 1886 and Scaptomyza Hardy, 1849, may have acquired this habit independently (LACY, 1984; HANSKI, 1989; Courtney et al., 1990). Yet, apparently this characteristic is synapomorphic in drosophilids of the Zygothrica genus group, a tropical taxa which includes the genera Hirtodrosophila Duda, 1923, Mycodrosophila Oldenberg, 1914, and Zygothrica Wiedemann, 1830 as main representatives (GRIMALDI, 1990).

Almost all studies on mycophagous drosophilids have been conducted in North America, Europe and Japan (COURTNEY et al., 1990; Burla et al., 1991; Toda et al., 1999; Yamashida \& HiJiI, 2007), and indicate that Drosophila is a genus that abounds in fungi fruiting bodies, and that it may even represent the majority of
Diptera that emerge from this substrate (ToDA et al., 1999). These investigations also offer evidences that most mycophagous Drosophila species known belong to the pinicola, quinaria, testacea and tripunctata species groups, all of which are included in the immigranstripunctata radiation (REMSEN \& O'GRADY, 2002; MARKOw \& O'GRADY, 2005).

Some of these temperate zone species were used as model organisms in several studies on field and experimental ecology and offered significant contributions. However, concerning the Neotropical region, the information available about this guild is scarce. Samples were obtained from the 1940's up to the 1960's (Frota-Pessoa, 1945, 1951; Cordeiro, 1952; Burla, 1956; Mourão et al., 1965), in studies whose aims were not to investigate the ecology of these species. Later, in a revision of the Zygothrica genus, Grimaldi (1987) collected individuals in Peru and observed that few 
species of the genus oviposit in fungi, while some use them as courtship site. VAL \& KANESHIRO (1988) carried out a survey in the Atlantic Rain Forest with commercial fungi and banana baits, and Zygothrica was the most abundant genus after Drosophila, with almost 50 species identified. Recently, RoQue et al. (2006) collected drosophilids flying over and emerging from fruiting bodies of Pleurotus sp. (Tricholomataceae, Agaricales) and another undetermined fungus at the Cerrado Biome, Central Brazil, where 20 species from five genera of Drosophilidae were collected, and Drosophila was the most abundant.

Although there have been important studies on the ecology of mycophagous drosophilids, they were conducted in temperate zones, where the diversity of Drosophilidae are lower than those found inhabiting other regions. Therefore, it becomes necessary to discover whether the processes and patterns found in temperate zones are applicable in tropical zones. In this context, the aim of the present study is to contribute to the understanding of the processes driving the colonizing patterns of mycophagous drosophilids, by analyzing and comparing the drosophilid assemblage associated to fruiting bodies of fungi in the Atlantic Rain Forest stricto sensu and anthropic areas, in south and southeastern Brazil.

\section{MATERIAL AND METHODS}

Drosophilids and fungi were collected in six sites in south (States of Rio Grande do Sul and Santa Catarina) and southeast regions of Brazil (State of São Paulo) (Fig. 1). Samplings were conducted at three environments of the Atlantic Rain Forest stricto sensu and three anthropic areas, near buildings or gardens (Tab. I).

To evaluate the probable feeding sites of mycophagous Drosophilidae species, adult flies flying over fructification bodies of fungi were captured in the field by sweeping with an entomological net or with an entomological aspirator. To assess the breeding sites of Drosophilidae species, fructification bodies of fungi were collected, brought to the laboratory and kept in glass vials with sterilized sand. Vials were maintained in controlled temperature at $24 \pm 1{ }^{\circ} \mathrm{C}$. Water was added whenever necessary to prevent dehydration. Emerged adults were aspired daily.

Drosophilid identification was based on external morphology and on male genitalia (prepared according to Wheeler \& Kambysellis, 1966, modified by KANESHIRO, 1969). Voucher specimens were deposited at the Museu de Ciências Naturais, Fundação Zoobotânica do Rio Grande do Sul (MCN/FZB), and Museu de Zoologia, Universidade de São Paulo (MZSP). Fungi identification was conducted using a dichotomic key (GUERRERO \& HOMRICH, 1999).

To test the association between drosophilid species and feeding sites, we conducted a Detrended Correspondence Analysis (DCA) (HiLl \& GAUCH, 1980), where the drosophilid species that flew over the fruiting bodies were the descriptors and fungi taxa were the objects. Another DCA was used to test an association between drosophilid species and breeding sites (fungi taxa), where the former were the descriptors and the latter the objects. DCA is an ordination analysis and, similarly to the Correspondence Analysis, it has been proposed as a way to analyze two-way contingence tables. However, DCA removes the arch effect found in most ordination analysis. DCA was conducted on the software R 2.5.0 (R Development Core Team, 2007), with the VEGAN package 1.8-8 (OKSANEN et al., 2007), and it was based on 26 segments, as recommended by HiLL \& GAUCH (1980).

\section{RESULTS}

A total of 910 individuals belonging to 31 Drosophilidae species were collected (Tabs. I, II). Among the drosophilid genera collected, Drosophila was the richest (17 species) and the most abundant in all environments sampled, even when compared to other exclusively mycophagous species, like Hirtodrosophila (five species), Leucophenga (two species) and Mycodrosophila (two species).

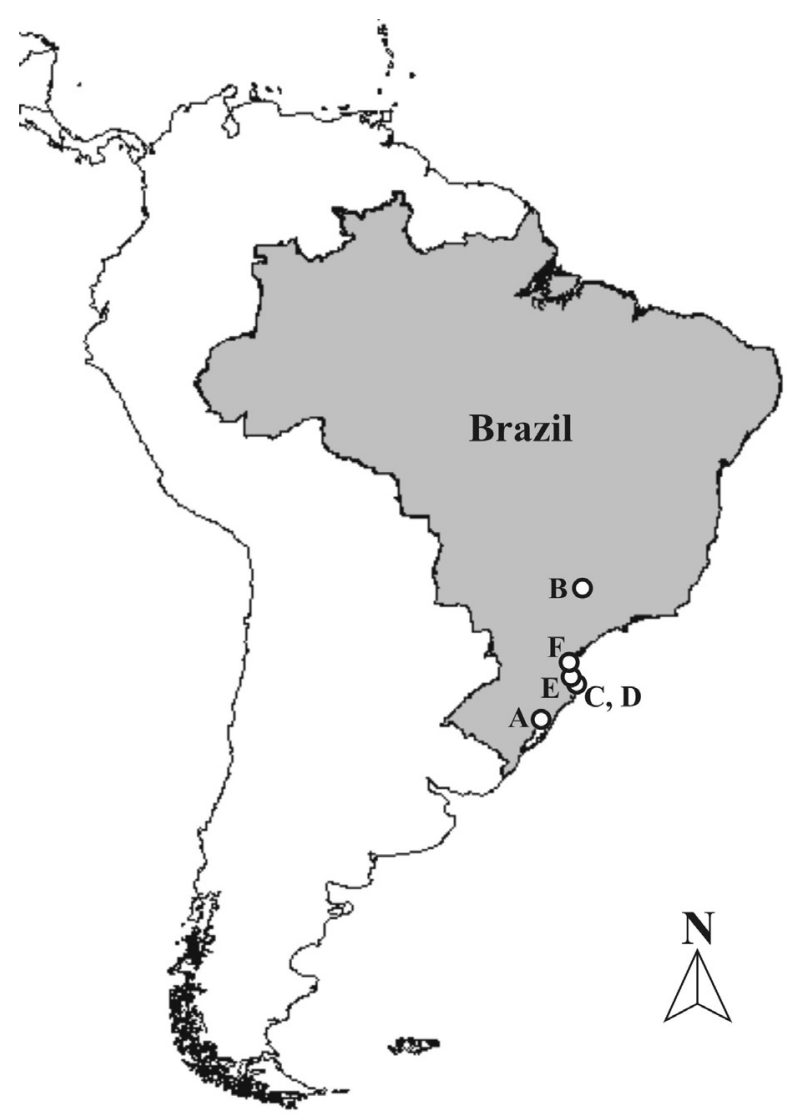

Figure 1. South America map indicating the sampled sites in Brazil of the Drosophilidae species associated to fruiting bodies of fungi in forested and anthropized environments (A, Campus of Universidade Federal do Rio Grande do Sul, Porto Alegre, RS; B, Campus of Universidade de São Paulo, Ribeirão Preto, SP; C, Campus of Universidade Federal de Santa Catarina, Florianópolis, SC; D, Morro da Lagoa da Conceição, Florianópolis, SC; E, Biguaçu, SC; F, Piraí, Joinville, SC). 
Considering all sites sampled, 90 individuals were collected flying over fructification bodies, totaling 21 fly species, of which 14 belonged to the genus Drosophila (Table III). At least four fungi species (probably used as feeding sites) were identified: Coprinus comatus (Agaricaceae, Agaricales), Phallus sp. (Phallaceae, Agaricales) and one species of Agaricales sampled in anthropic areas; one member of the Polyporaceae family and a group of several undetermined fungi species sampled in forest areas. In the DCA conducted for the specimens collected flying over fruiting bodies, the components 1 and 2 accounted for $40.9 \%$ of data variation. Our analysis distinguished between generalist and specialist fly species (Fig. 2).

Table I. Sampling sites of the Drosophilidae species associated to fruiting bodies of fungi, co-ordinates, and their respective environment types.

\begin{tabular}{lcc}
\hline Sampled Sites & Co-ordinates & Environments \\
\hline A Campus of Universidade Federal do Rio Grande do Sul, Porto Alegre, RS & $30^{\circ} 04^{\prime} 16.1^{\prime \prime}, 5 ; 1^{\circ} 07^{\prime} 13.7^{\prime \prime} \mathrm{W}$ & anthropic area \\
B Campus of Universidade de São Paulo, Ribeirão Preto, SP & $21^{\circ} 10^{\prime} 11.7^{\prime \prime} \mathrm{S} ; 47^{\circ} 51^{\prime} 33.4$ ', W & anthropic area \\
C Campus of Universidade Federal de Santa Catarina, Florianópolis, SC & $27^{\circ} 36^{\prime} 12.9^{\prime \prime}, \mathrm{S} ; 48^{\circ} 31^{\prime} 21.9^{\prime \prime} \mathrm{W}$ & anthropic area \\
D Morro da Lagoa da Conceição, Florianópolis, SC & $27^{\circ} 35^{\prime} 26.8^{\prime \prime}, \mathrm{S} ; 8^{\circ} 28^{\prime} 32.9^{\prime \prime} \mathrm{W}$ & Atlantic Rain Forest \\
E Biguaçu, SC & $27^{\circ} 29^{\prime} 09.8^{\prime \prime}, \mathrm{S} ; 48^{\circ} 39^{\prime} 17.7^{\prime \prime} \mathrm{W}$ & Atlantic Rain Forest \\
F Piraí, Joinville, SC & $26^{\circ} 17^{\prime} 37.9^{\prime \prime} \mathrm{S} ; 49^{\circ} 00^{\prime} 56.4^{\prime \prime} \mathrm{W}$ & Atlantic Rain Forest \\
\hline
\end{tabular}

Table II. Fungi taxa, dates of collections, sampled sites (A, Campus of Universidade Federal do Rio Grande do Sul, Porto Alegre, RS; B, Campus of Universidade de São Paulo, Ribeirão Preto, SP; C, Campus of Universidade Federal de Santa Catarina, Florianópolis, SC; D, Morro da Lagoa da Conceição, Florianópolis, SC; E, Biguaçu, SC; F, Piraí, Joinville, SC) and size (number of fruiting bodies) of each sample.

\begin{tabular}{|c|c|c|c|c|c|}
\hline Code & Collected fungi species & Date & Site & Methods of collection & Sample size \\
\hline F1 & Coprinus comatus (Agaricaceae) & 15.VII.2005 & A & Feeding sites & - \\
\hline F2 & Coprinus comatus (Agaricaceae) & 04.VIII.2005 & A & Feeding sites & - \\
\hline F3 & Phallus sp. (Phallaceae) & 20.III.2006 & B & Feeding sites & - \\
\hline F4 & Agaricales sensu lato & 22.I.2007 & B & Feeding sites & - \\
\hline F5 & Polyporaceae & 07.IV. 2007 & $\mathrm{D}$ & Feeding sites & - \\
\hline F6 & Group of several undetermined fungi species & 07.IV. 2007 & $\mathrm{D}$ & Feeding sites & - \\
\hline B 1 & Macrolepiota sp. (Agaricaceae) & 07.III.2005 & $\mathrm{C}$ & Breeding sites & One fruiting body \\
\hline B2 & Marasmius sp. (Marasmiaceae) & 07.III.2005 & $\mathrm{C}$ & Breeding sites & 200 fruiting bodies \\
\hline B3 & Polyporaceae & 07.III.2005 & $\mathrm{D}$ & Breeding sites & 75 fruiting bodies \\
\hline B4 & Polyporaceae & 07.III.2005 & $\mathrm{D}$ & Breeding sites & 75 fruiting bodies \\
\hline B5 & Polyporaceae & 07.VI.2005 & A & Breeding sites & 54 fruiting bodies \\
\hline B6 & Polyporaceae & 13.XI.2006 & $\mathrm{E}$ & Breeding sites & 50 fruiting bodies \\
\hline B7 & Agaricales sensu lato & 24.V.2005 & $\mathrm{C}$ & Breeding sites & 125 fruiting bodies \\
\hline B8 & Auricularia sp. (Auriculariaceae) & 03.XI.2005 & $\mathrm{F}$ & Breeding sites & $\begin{array}{l}\text { Unknown number of } \\
\text { fruiting bodies }\end{array}$ \\
\hline B9 & Auricularia sp. (Auriculariaceae) & 13.XI.2006 & $\mathrm{E}$ & Breeding sites & 30 fruiting bodies \\
\hline B 10 & Coprinus comatus (Agaricaceae) & 15.IV.2005 & A & Breeding sites & 17 fruiting bodies \\
\hline B 11 & Coprinus comatus (Agaricaceae) & 15.VII.2005 & A & Breeding sites & 66 fruiting bodies \\
\hline B12 & Coprinus comatus (Agaricaceae) & 04.VIII.2005 & A & Breeding sites & 162 fruiting bodies \\
\hline
\end{tabular}

Table III. Drosophilidae species collected flying over fungi fruiting bodies in different sites in Brazil (F1, Coprinus comatus, anthropic area; F2, C. comatus, anthropic area; F3, Phallus sp., anthropic area; F4, Agaricales sensu lato, anthropic area; F5, Polyporaceae, Atlantic Rain Forest area; F6, Group of several undetermined fungi species, Atlantic Rain Forest area). *Same species introduced by Gottschalk et al. (2007).

\begin{tabular}{|c|c|c|c|c|c|c|c|c|c|}
\hline Genus & Group & Species & F1 & F2 & F3 & F4 & F5 & F6 & Total \\
\hline \multirow[t]{14}{*}{ Drosophila } & calloptera & D. atrata Burla \& Pavan, 1953 & & & & & 2 & & 2 \\
\hline & & D. calloptera Schiner, 1868 & & & & & 1 & & 1 \\
\hline & cardini & D. cardini Sturtevant, 1916 & & & & 3 & & & 3 \\
\hline & & D. cardinoides Dobzhansky \& Pavan, 1943 & & 1 & & 2 & & & 3 \\
\hline & & D. neocardini Streisinger, 1946 & & & & 1 & & & 1 \\
\hline & guarani & D. griseolineata Duda, 1927 & 4 & 5 & & & & 6 & 15 \\
\hline & & D. maculifrons Duda, 1927 & & 1 & & & & & 1 \\
\hline & immigrans & D. immigrans Sturtevant, 1921 & & 2 & & & & & 2 \\
\hline & melanogaster & D. kikkawai Burla, 1954 & & 1 & & & & & 1 \\
\hline & tripunctata & D. cuaso Bächli, Vilela \& Ratcov, 2000 & & 2 & & & & 4 & 6 \\
\hline & & D. mediopunctata Dobzhansky \& Pavan, 1943 & 3 & 3 & & & & 1 & 7 \\
\hline & & D. paraguayensis Duda, 1927 & & & & & & 10 & 10 \\
\hline & & D. roehrae Pipkin \& Heed, 1964 & & & & & & 5 & 5 \\
\hline & willistoni & D. willistoni subgroup & 3 & 3 & & & & & 6 \\
\hline \multirow{2}{*}{ Hirtodrosophila } & hirticornis & H. gilva (Burla, 1956) & & & & & & 1 & 1 \\
\hline & & Hirtodrosophila sp. ob1 (sp. Z3*) & & & & & & 4 & 4 \\
\hline Leucophenga & & Leucophenga sp.1 & & & & 2 & & & 2 \\
\hline Mycodrosophila & & M. projectans (Sturtevant, 1916) & 1 & & & & & & 1 \\
\hline Zaprionus & vittiger & Z. indianus Gupta, 1970 & & & 12 & & & & 12 \\
\hline \multirow[t]{2}{*}{ Zygothrica } & hypandriata & Z. hypandriata Burla, 1956 & & 2 & & & & & 2 \\
\hline & & Zygothrica sp. & & & & 5 & & & 5 \\
\hline Total & & & 11 & 20 & 12 & 13 & 3 & 31 & 90 \\
\hline
\end{tabular}


Generalist Drosophilidae species generated dots closer to the point of origin of axes, and occurred mainly in association with $C$. comatus samples, that was found in the anthropized environments and which had also more homogeneous assemblages. The dots of the more specialist drosophilids are farther away from the point of origin, just as the dots representing more heterogeneous assemblages associated to feeding sites.

Specimens of four fungi families (Agaricaceae, Auriculariaceae, Marasmiaceae and Polyporaceae) were collected and brought to the laboratory, of which 820 drosophilids emerged (Tab. IV). Drosophila was once again the richest and most abundant genus, with ten species and 273 individuals. In the DCA for species that emerged from the fructification bodies (breeding sites) (Fig. 3), the components 1 and 2 accounted for $14.8 \%$ of data variation. Exactly as observed in feeding sites, the composition of breeding Drosophilidae from fungi of anthropized areas (C. comatus, Macrolepiota sp., Marasmius sp. and Agaricales latu sensu) was more homogeneous. Similar situation was observed regarding the presence of more generalist species. This is highlighted by the clustering of dots next to the point of origin of the chart's axes. The fauna emerged from Polyporacea, that was found mainlly in the forest areas, was typical and distinct from that of other fungi, including specialized Drosophilidae genera, as Hirtodrosophila, Mycodrosophila and Zygothrica. The Atlantic Rain Forest samples were likewise more heterogeneous regarding composition of colonizing species (evidenced by respective dots distant from the point of origin), and the species that colonized fungi from the woods were observed exclusively in these samples.

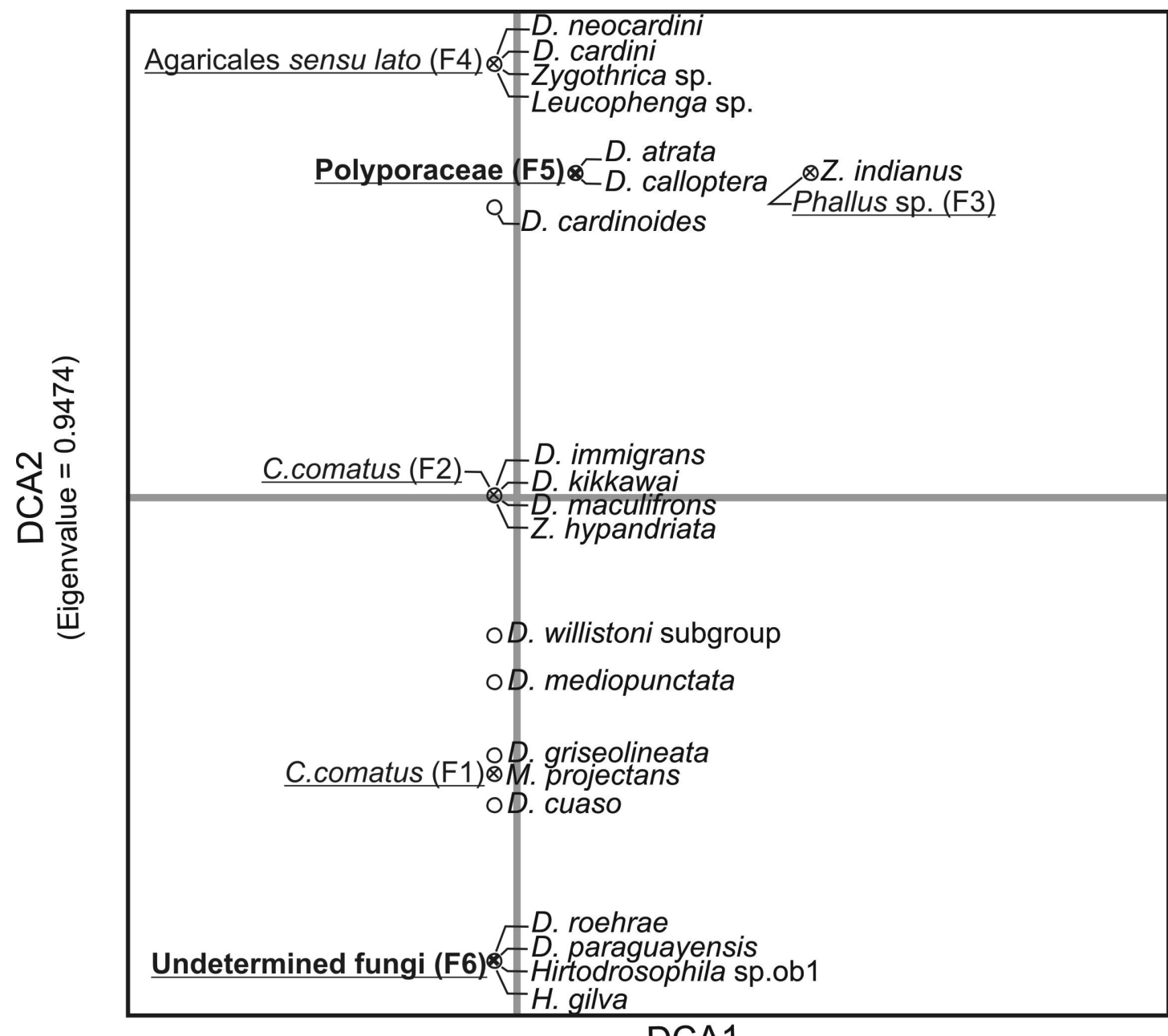

DCA1

(Eigenvalue $=1.0)$

oDrosophilidae species
$\times$ Fungus species in antropic area
$\times$ Fungus species in Atlantic Rain Forest

Figure 2. Detrended Correspondence Analysis results for feeding sites data. DCA1, component 1; DCA2, component 2; circles, Drosophilidae species; cross and underlined text: fungi species collected in anthropized environment; cross and underlined text in bold: fungi species collected in Atlantic Rain Forest. 
Table IV. Drosophilidae species emerged from fungi fruiting bodies in different sites in Brazil (B1, Macrolepiota sp., Atlantic Rain Forest area; B2, Marasmius sp., Atlantic Rain Forest area; B3, Polyporaceae, Atlantic Rain Forest area; B4, Polyporaceae, Atlantic Rain Forest area; B5, Polyporaceae, anthropic area; B6, Polyporaceae, Atlantic Rain Forest area; B7, Agaricales sensu lato, anthropic area; B8, Auricularia sp., Atlantic Rain Forest area; B9, Auricularia sp., Atlantic Rain Forest area; B10, Coprinus comatus, anthropic area; B11, C. comatus, anthropic area; B12, C. comatus, anthropic area). *Same species introduced by GotTschalk et al. (2007).

\begin{tabular}{|c|c|c|c|c|c|c|c|c|c|c|c|c|c|c|c|}
\hline Genus & Group & Species & $\mathrm{B} 1$ & B2 & B3 & $\mathrm{B} 4$ & B5 & B6 & B7 & B8 & B9 & $\mathrm{B} 10$ & B11 & $\mathrm{B} 12$ & Total \\
\hline \multirow{10}{*}{ Drosophila } & cardini & D. cardini Sturtevant, 1916 & & & & & & & & & & 39 & & 2 & 41 \\
\hline & & $\begin{array}{l}\text { D. cardinoides Dobzhansky } \\
\text { \& Pavan, } 1943\end{array}$ & & 28 & & & & & 4 & & & 28 & 97 & 8 & 165 \\
\hline & & D. neocardini Streisinger, 1946 & & 5 & & & & & & & & 2 & & & 7 \\
\hline & guarani & Drosophila sp. gu2 (sp. G1*) & & & & & & & & 2 & & & & & 2 \\
\hline & immigrans & D. immigrans Sturtevant, 1921 & & & & & & & & & & & & 1 & 1 \\
\hline & melanogaster & D. kikkawai Burla, 1954 & & & & & & & & & & & 6 & 4 & 10 \\
\hline & tripunctata & $\begin{array}{l}\text { D. cuaso Bächli, Vilela } \\
\text { \& Ratcov, } 2000\end{array}$ & & & & & & & & 12 & & 1 & & & 13 \\
\hline & & $\begin{array}{l}\text { D. mediovittata Frota-Pessoa, } \\
1954\end{array}$ & & & & & & & & & & & 1 & 1 & 2 \\
\hline & & $\begin{array}{l}\text { D. nappae Vilela, Valente } \\
\text { \& Basso-da-Silva, } 2004\end{array}$ & & & & & & & & & & 17 & 10 & & 27 \\
\hline & & D. paraguayensis Duda, 1927 & & & & & & 5 & & & & & & & 5 \\
\hline \multirow[t]{3}{*}{ Hirtodrosophila } & hirticornis & H. gilva (Burla, 1956) & & & & & & & & & 181 & & & & 181 \\
\hline & thoracis & H. thoracis (Williston, 1896) & & 142 & & 3 & & 3 & 18 & & & & & & 166 \\
\hline & $\begin{array}{l}\text { not assigned } \\
\text { to group }\end{array}$ & H. ramulosa (Burla, 1956) & & & & & & & & & 19 & & & & 19 \\
\hline Leucophenga & & Leucophenga sp. 2 & 34 & & & & & & 16 & & & & & & 50 \\
\hline \multirow[t]{2}{*}{ Mycodrosophila } & & M. projectans (Sturtevant, 1916) & & & 9 & 21 & 2 & 4 & & & & & 1 & & 37 \\
\hline & & Mycodrosophila sp. 2 & & & 3 & & & & & & & & & & 3 \\
\hline Scaptomyza & & S. hirsuta (cf.) Wheeler, 1949 & & & & & & & & & & & 1 & 1 & 2 \\
\hline \multirow[t]{4}{*}{ Zygothrica } & atriangula & Z. poeyi (Sturtevant, 1921) & & & & & & 1 & & & & & & & 1 \\
\hline & hypandriata & Z. hypandriata Burla, 1956 & & & & & & & & & & & 1 & 63 & 64 \\
\hline & & Zygothrica sp. 1 & & & 13 & & & & & & & & & & 13 \\
\hline & & Zygothrica sp. 2 & & 1 & 10 & & & & & & & & & & 11 \\
\hline Total & & & 34 & 176 & 35 & 24 & 2 & 13 & 38 & 14 & 200 & 87 & 117 & 80 & 820 \\
\hline
\end{tabular}

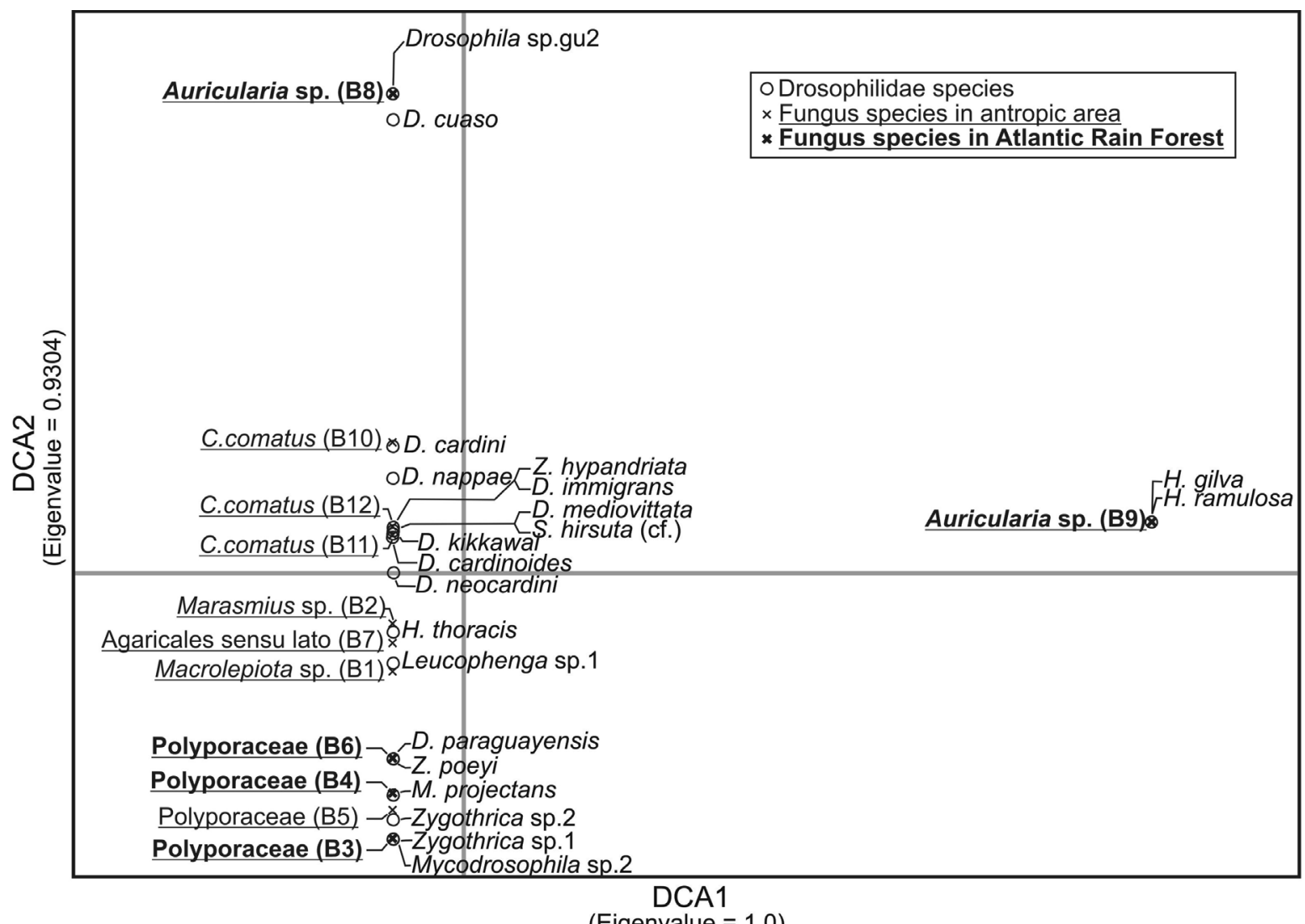

$($ Eigenvalue $=1.0)$

Figure 3. Detrended Correspondence Analysis results for breeding sites data. DCA1, component 1; DCA2, component 2; circles, Drosophilidae species; cross and underlined text: fungi species collected in anthropized environment; cross and underlined text in bold: fungi species collected in Atlantic Rain Forest. 


\section{DISCUSSION}

As a whole, our results indicate that mycophagy is far more common than previously thought, since the present records expands the mycophagous habit (feeding or breeding on fungi) to almost all species groups of immigrans-tripunctata in the Neotropical region, even those supposed to be exclusively frugivorous. The species of calloptera, cardini, guarani and tripunctata species groups of Drosophila, all belonging to the immigrans-tripunctata radiation (REMSEN \& O'GRADY, 2002; MARKOW \& O'GRADY, 2005), were frequent in our samples (except for Polyporaceae). The same had been previously observed in a study conducted in central Brazil by Roque et al. (2006). Most of the species belonging to the testacea and quinaria species groups of Drosophila, which also belong to the immigrans-tripunctata radiation, are obligatory mycophagous flies. The characteristics related to the use of fungi by species of the immigranstripunctata radiation may thus be synapomorphic, since all its species groups, with the exception of pallidipennis, were recorded colonizing fungi. However, the homoplasy hypothesis cannot be rejected.

The occurrence of Hirtodrosophila, Leucophenga, Mycodrosophila, Scaptomyza and Zygothrica in fungi lends more consistency to the existing literature records (Grimaldi, 1987; Val \& Kaneshiro, 1988; Courtney et al., 1990). Nevertheless, the presence of Zaprionus Coquillett, 1901 in our samples attracted our interest, as the only species observed in the Neotropics, Z. indianus, is considered to be frugivorous. Adult specimens of $Z$. indianus were collected over fruiting bodies of Phallus sp. (Phallaceae, Phallales) in anthropized areas of Ribeirão Preto (São Paulo, Brazil), and two individuals emerged from fungi collected by RoQuE et al. (2006). Taken together, these data demonstrate the versatility of this species, which recently invaded the American continent and is considered a pest for fruit production (VILELA et al., 2000).

Drosophilid assemblages associated to Polyporaceae were distinct from that associated to fungi of other families, considering both breeding and feeding sites. The dominance of Hirtodrosophila, Mycodrosophila and Zygothrica species may be linked to higher frequencies of this fungus family in Atlantic Rain Forest areas, since it is possible that the richness of these drosophilid genera is higher in forests, as suggested by SPIETh (1987) and CourTney et al. (1990). In these forested areas, the assemblages were more heterogeneous regarding their composition. In contrast, the fauna emerging from the Agaricaceae, Auriculariaceae, Marasmiaceae and Phallaceae families, more abundant at anthropized areas, was far more homogeneous, with dominance of Drosophila species.

In the present study, the cardini species group of Drosophila (D. cardini Sturtevant, 1916, D. cardinoides Dobzhansky \& Pavan, 1943 and D. neocardini Streisinger, 1946) was restricted to the anthropized environments, since these species were observed only in fungi collected in these areas. The low abundance of such species in forested areas, in contrast with the high abundance observed in anthropic ones, was also recorded by GotTschalk et al. (2007), though using banana baits.
Similarlly, the calloptera group, in spite of the low abundance observed, was restricted to forest areas, what have also been observed in banana-baited collections (DE Toni et al., 2007). On the other hand, species of the tripunctata and guarani species groups were observed in fungi collected in both forested and anthropized environments.

In the present study, 31 Drosophilidae species were collected associated to fungi fruiting bodies in the Atlantic Rain Forest and urbanized areas. Of these species, those belonging to the Drosophila and Zaprionus genera were also collected associated to fruits in other studies (CARSON, 1971; Silva et al., 2005; GARCIA et al., 2008), demonstrating their versatility in resource use. The use of fungi as a trophic resource has probably played a more significant role, in comparison to previous notions, in the evolutive success of Neotropical species belonging to the immigrans-tripunctata radiation of Drosophila. Assemblages associated to fungi of forested areas were more heterogeneous in terms of species composition, while those associated to fungi of anthropized areas were more homogeneous at species level. The species of the cardini groups of Drosophila was restricted to anthropized areas, while the calloptera species group was restricted to forested areas. The drosophilids from anthropized areas were also more versatile in resource use, since they were collected in several samples of feeding and breeding sites.

Acknowledgments. The authors are grateful to Monica Laner Blauth, Diogo Andrade Costa, Rosana Tidon, Victor Hugo Valiati, Helena Piccoli Romanowski and two anonymous referees for the suggestions kindly offered as of manuscript preparation, to Juliana Cordeiro and Hermes José Schmitz for the assistance in the collections, to Felix Nonnenmacher for the help with English version of the manuscript, and to Coordenação de Aperfeiçoamento de Pessoal de Nível Superior (CAPES), Conselho Nacional de Desenvolvimento Científico e Tecnológico (CNPq) and the Fundação de Apoio da Universidade Federal do Rio Grande do Sul (FAURGS) for the financial support granted.

\section{REFERENCES}

Burla, H. 1956. Die Drosophilidengattung Zygothrica und ihre beziehung zur Drosophila-untergattung Hirtodrosophila. Mitteilungen aus dem Zoologischen Museum in Berlin 32:189-321.

Burla, H.; B̈̈chli, G. \& Huber, H. 1991. Drosophila reared from the stinkhorn, Phallus impudicus, near Zurich, Switzerland. Journal of Zoological Systematics and Evolutionary Research 29:97-107.

CARson, H. L. 1971. The ecology of Drosophila breeding sites. Honolulu, University of Hawaii. 27p.

Cordeiro, A. R. 1952. Drosophila (Hirtodrosophila) caxiensis, a new species of fungus-feeding fly from Brasil. Dusenia 3:303308 .

Courtney, S. P.; Kibota, T. T. \& Singleton, T. A. 1990. Ecology of mushroom-feeding Drosophilidae. Advances in Ecological Research 20:225-274.

De Toni, D. C.; Gottschalk, M. S.; Cordeiro, J.; Hofmann, P. R. P. \& Valente, V. L. S. 2007. Assemblages on Atlantic Forest Islands of Santa Catarina State. Neotropical Entomology 36:356-375.

Frota-Pessoa, O. 1945. Sobre o subgênero Hirtodrosophila, com descrição de uma nova espécie (Dipt., Drosophilidae, Drosophila). Revista Brasileira de Entomologia 5:469-483. 1951. Drosophila (Hirtodrosophila) magnarcus n. sp. (Diptera, Drosophilidae). Revista Brasileira de Biologia 11:407-411. 
Garcia, A. C. L.; Valiati, V. H.; Gottschalk, M. S.; Rohde, C. \& VALENTE, V. L. S. 2008. Two decades of colonization of the urban environment of Porto Alegre, southern Brazil, by Drosophila paulistorum (Diptera, Drosophilidae). Iheringia, Série Zoologia 98:329-338.

Gottschalk, M. S.; De Toni, D. C.; Valente, V. L. \& Hofmann, P. R. P. 2007. Changes in Brazilian Drosophilidae (Diptera) assemblages across an urbanisation gradient. Neotropical Entomology 36:848-862.

Grimaldi, D. A. 1987. Phylogenetics and taxonomy of Zygothrica (Diptera: Drosophilidae). Bulletin of the American Museum of Natural History 186:103-268.

1990. A phylogenetic, revised classification of genera in the Drosophilidae (Diptera). Bulletin of the American Museum of Natural History 197:1-139.

Guerrero, R. T. \& Homrich, M. H. 1999. Fungos macroscópicos comuns no Rio Grande do Sul. $2^{\text {a }}$ ed. Porto Alegre, Editora da Universidade/UFRGS. 124p.

Hanski, I. 1989. Fungivory: fungi, insects and ecology. In: WiLding, N.; Collins, N. M.; Hammond, P. M. \& Webber, J. B. eds. Insect-fungus interaction. 14th Symposium of Royal Entomological Society London. London, Academic. p.25-68.

Hill, M. O. \& GAUCH, JR., H. G. 1980. Detrended correspondence analysis: an improved ordination technique. Vegetatio 42:47-58.

Kaneshiro, K. Y. 1969. A study of the relationships of Hawaiian Drosophila species based on the external male genitalia. The University of Texas Publication 6918:55-69.

LACY, R. C. 1984. Predictability, toxicity, and trophic niche breadth in fungus-feeding Drosophilidae (Diptera). Ecological Entomology 9:43-54.

Markow, T. A. \& O'Grady, P. M. 2005. Drosophila: A guide to species identification and use. London, Academic. $259 \mathrm{p}$.

Mourão, C. A.; Gallo, A. J. \& Bicudo, H. E. M. C. 1965. Sôbre a sistemática de Drosophila no Brasil, com descrição de $D$. mendeli sp.n. e "Relação de espécies brasileiras do gênero Drosophila". Ciência e Cultura 17:577-586.

Oksanen, J.; Kindt, R.; Legendre, P.; O’Hara, B. \& Stevens, M. H. H. 2007. Vegan: Community Ecology Package. R package version 1.8-8. Available at: 〈http://cran.r-project.org〉. Access on: 23.09 .2007$.

R Development Core Team. 2007. R: A language and environment for statistical computing. Vienna, $R$ Foundation for Statistical Computing. Available at: <http:// www.R-project.org>. Access on: 23.09.2007.

Remsen, J. \& O'Grady, P. 2002. Phylogeny of Drosophilinae (Diptera: Drosophilidae), with comments on combined analysis and character support. Molecular Phylogenetics and Evolution 24:249-264.

Roque, F.; Figueiredo, R. \& Tidon, R. 2006. Nine new records of drosophilids in the Brazilian savanna. Drosophila Information Service 89:14-17.

Silva, N. M.; Fantinel, C. C.; Valente, V. L. S. \& Valiati, V. H. 2005. Ecology of colonizing populations of the figfly Zaprionus indianus (Diptera, Drosophilidae) in Porto Alegre, Southern Brazil. Iheringia, Série Zoologia 95:233-240.

Spieth, H. T. 1987. The Drosophila fauna of a native California forest (Diptera: Drosophilidae). Pan-Pacific Entomologist 63:247-255.

THROCKMORTON, L. H. 1975. The phylogeny, ecology and geography of Drosophila. In: KING, R. C. ed. Handbook of Genetics. New York, Plenum Press. p.421-469.

Toda, M. J.; Kimura, M. T. \& Tuno, N. 1999. Coexistence mechanisms of mycophagous drosophilids on multispecies fungal hosts: aggregation and resource partitioning. Journal of Animal Ecology 68:794-803

VAL, F. C. \& Kaneshiro, K. Y. 1988. Drosophilidae (Diptera) from the Estação Biológica de Boracéia, on the coastal range of the state of São Paulo, Brazil: geographical distribution. In: Vanzolini, P. E. \& Heyer, W. R. eds. Proceedings of a workshop on Neotropical distribution patterns. p.189-203.

Vilela, C. R.; Teixeira, E. P. \& Stein, C. P. 2000. Mosca-africanado-figo, Zaprionus indianus (Diptera, Drosophilidae). In: Vilela, E. F.; Zucchi, R. A. \& CANTor, F. eds. Histórico e impacto das pragas introduzidas no Brasil. Ribeirão Preto, Holos. p.48-52.

Wheeler, M. R. \& Kambysellis, M. P. 1966. Notes on the Drosophilidae (Diptera) of Samoa. The University of Texas Publication 6615:533-565.

Yamashida, S. \& HiJII, N. 2007. The role of fungal taxa and developmental stage of mushrooms in determining the composition of the mycophagous insect community in a Japanese forest. European Journal of Entomology 104:225-233.

Recebido em julho de 2008. Aceito em julho de 2009. ISSN 0073-4721

Artigo disponível em: www.scielo.br/isz 